\title{
EAl Endorsed Transactions

\section{Increasing motivation for cancer treatment adherence in children through a mobile educational game: a pilot study}

\author{
Carmen Chai Wang Er ${ }^{1 *}$, Lau Bee Theng ${ }^{1}$, Mark Tee Kit Tsun ${ }^{1}$ and Abdullah Al Mahmud ${ }^{2}$ \\ ${ }^{1}$ Swinburne University of Technology - Sarawak Campus, Kuching, Sarawak, Malaysia \\ ${ }^{2}$ Swinburne University of Technology, Melbourne, Victoria, Australia
}

\begin{abstract}
INTRODUCTION: It is crucial to educate childhood cancer patients (CCPs) about their illness and motivate them for cancer treatment and treatment side-effects management.

OBJECTIVES: This paper describes the design, development and pilot evaluation of the proposed serious game intervention with CCPs in Malaysia.

METHODS: A single-centre, single-arm intervention was conducted with CCPs $(n=8)$. Surveys were done pre-test and post-

test.

RESULTS: The Protection Motivation Theory was used to measure the participants' motivation. Self-reported surveys with CCPs and caregiver dyads showed a significant increase in participants' intention to use cancer treatment. Although the increase in the intention to use daily self-care and cancer knowledge survey scores was not substantial, the post-test caregivers' feedback revealed that the game was beneficial for their children.

CONCLUSION: Early results of the study have shown the intervention's potential to boost the knowledge and motivations of CCPs.
\end{abstract}

Keywords: childhood cancer, e-learning, mobile application, serious game, treatment adherence, virtual pet.

Received on 05 January 2022, accepted on 09 February 2022, published on 15 February 2022

Copyright (C) 2022 Carmen Chai Wang Er et al., licensed to EAI. This is an open access article distributed under the terms of the Creative Commons Attribution license, which permits unlimited use, distribution and reproduction in any medium so long as the original work is properly cited.

doi: 10.4108/eai.15-2-2022.173453

\section{Introduction}

\subsection{Background}

Childhood cancer, the number one cause of death via illness in children, has a survival rate of $80 \%$ in high-income countries with treatment [1]. However, cancer treatment is a long and challenging experience for young patients [2], resulting in many taxing treatment side effects [3-5]. Due to these factors, childhood cancer patients and their families may not adhere fully to treatment and may even resort to treatment abandonment [6]. Many of these treatment side- effects can be managed through daily self-care, such as maintaining good bodily and oral hygiene [5,7], having a healthy diet [3,8], having sufficient fluid intake[9,10], and ample rest[11]. In addition, age-appropriate information on their illness can help children and adolescent cancer patients to cope with the cancer experience $[12,13]$.

Play-based interventions, whether in real-life or in digital forms, such as serious games, can increase cognitive, emotional, social and physical development in children with chronic diseases [14]. Digital health interventions are highly appealing to the younger generation who embrace electronics and technology [15]. Even young children have become acquainted with interactive technology at a young age and are adept at using devices independently [16]. Therefore, the interventions developed for the young generation of patients 
should consider using technology whenever possible, and be in the form of e-learning tools, m-health tools or serious games for health.

\subsection{Purpose of the Study}

This pilot study aims to assess and explore the effectiveness of a serious game intervention to motivate children with cancer to adhere to their treatment, encourage daily self-care, and educate them about cancer and cancer treatment. The serious game intervention is developed using theory-based strategies that promote healthy behaviours. This paper reports the development and pilot evaluation of Pets vs Onco, a virtual pet mobile game for young cancer patients.

\section{Research Theories Guiding the Intervention Design}

\subsection{Protection Motivation Theory}

As an important aspect of the intervention is to motivate childhood cancer patients to go through cancer treatment, the Protection Motivation Theory (PMT) [17,18] was employed to guide the intervention's development. This theory is a health belief model used to understand how and why various individuals respond to potential health threats to themselves and have been used in many health interventions to motivate health behaviours [19-21].

A person's intention to take up a health behaviour is affected by seven factors divided into two categories. The first category, threat appraisal, consists of perceived severity, perceived vulnerability, intrinsic and extrinsic rewards, and fear arousal. The second category is the coping appraisal, and this consists of perceived response-efficacy, perceived selfefficacy and response cost.

As both childhood cancer and cancer treatment sideeffects are strong health threats, this intervention focuses on the coping appraisal aspect of the PMT. It should boost the patients' response efficacy and self-efficacy for 1) adhering to their cancer treatment to fight cancer and 2) practising daily self-care to counter cancer treatment side-effects.

\subsection{Social Learning Theory}

Another theory that was used to shape the design of the intervention is the Social Learning Theory [22]. This theory hypothesizes that people can learn from one another in a social context through imitation, observation, and modelling.

The Social Learning Theory has been utilized to teach sun protection to young children through observational learning [23] via clown characters who act as role models to convey the desired health behaviour to pre-school children. Another example of observational learning is the mobile application "Veggie Maths Masters" [24], which encourages the acceptance of vegetables in young children by depicting characters enjoying vegetables. Therefore, the game intervention should utilize role models to convey good health behaviours to children.

\section{Game Design and Development}

Before developing the intervention, the researchers reviewed the aims and related game mechanics of digital health interventions for children with cancer [25] to inform the design of the serious game. The findings support the use of the following game mechanics: "fighting enemies" to empower young cancer patients to fight their illness, "rolemodelling" to demonstrate good health behaviours, and game mechanics that encourage continuous gameplay such as "custom avatars", "randomly generated levels" and "virtual rewards", "unlockables", and "quests and challenges". The game intervention has also been suggested to be a mobile game for its portability.

The conceptual design of this game intervention [26] has established that the virtual pet is suitable for the game's intervention as it can demonstrate the importance of daily self-care. A virtual pet emulates a real pet that humans can interact with and can take the form of an electronic toy, robot, or game [27]. Players can gain the confidence to improve their awareness of taking care of their health by taking care of their virtual pet [28]. Virtual pets were used as health interventions for children to promote health management such as asthma [28] and encouraged good health habits to prevent obesity, such as increased physical exercise and eating healthily $[29,30]$.

The Pets vs Onco game required several resources in its design and development. The primary development tools include a game engine for creating a $2 \mathrm{D}$ mobile game and other resources such as artwork and sounds. Unity 5 is selected as the game engine for the development, as it supports the C\# language. Unity 5 was chosen as it supports the development of 2D mobile games, and is well documented, with many development tutorials available. Adobe Photoshop was used to create sprites and user interface items for the artwork required. Due to the resources constraint, some free-to-use online image resources were included. Royalty-free music, sound effects, and sound clips were obtained from online resources. Whenever required, the Audacity software was also used to edit the game's audio.

As mentioned previously, the development of the current game prototype [31] was guided by two theories: the Protection Motivation Theory (PMT) and the Social Learning Theory (SLT). The key game modules of Pets vs Onco are summarized in Table 1 below. 
Table 1. Key Game Modules of Pets vs Onco

\begin{tabular}{|c|c|}
\hline Game Module & Description \\
\hline $\begin{array}{l}\text { Related Theories: } \\
\text { PMT and SLT }\end{array}$ & $\begin{array}{l}\text { - Highlights the importance of taking daily care of one's health } \\
\text { - The pet has a few health statuses that the player needs to care for, such as } \\
\text { hunger, thirst, rest, and cleanliness } \\
\text { - A cancer treatment status is also included, which the player can maintain } \\
\text { through the mini-games module }\end{array}$ \\
\hline $\begin{array}{l}\text { Related Theories: } \\
\text { PMT and SLT }\end{array}$ & $\begin{array}{l}\text { - Modelled after cancer treatments to allow the player to virtually fight cancer } \\
\text { - The ability to fight cancer in a game can empower players to fight the disease } \\
\text { and also boost treatment adherence [32] } \\
\text { - The three mini-games are: } \\
\text { 1) Onco Blast - modelled after chemotherapy, is a horizontal space shooter } \\
\text { game where the pet shoots medicine out of a rocket ship at bad cancer cells } \\
\text { 2) Radio Beam Attack - modelled after radiotherapy, is a whack-a-mole style } \\
\text { game where players can tap on the bad cancer cells to blast them with a } \\
\text { radio beam } \\
\text { 3) Onco Slash - modelled after surgery, in this mini-game, players can draw on } \\
\text { the screen to "slash" at a group of bad cancer cells while avoiding the good } \\
\text { body cells } \\
\text { - Players can earn star coins currency through playing mini-games, which can } \\
\text { be used at the Shop Module }\end{array}$ \\
\hline $\begin{array}{l}\text { Educational Module } \\
\text { Related Theories: } \\
\text { PMT }\end{array}$ & $\begin{array}{l}\text { - Includes a library module where players can read about basic cancer, cancer } \\
\text { treatment and self-care related facts } \\
\text { - It also includes a quiz-based mini-game where players can be quizzed on the } \\
\text { knowledge they can learn from the library module } \\
\text { - Content of these modules are written at children's reading levels and are } \\
\text { phrased in a positive and child-friendly manner }\end{array}$ \\
\hline $\begin{array}{l}\text { Alarm Module } \\
\text { Related Theories: } \\
\text { PMT }\end{array}$ & $\begin{array}{l}\text { - Provides a way for players and their families to set reminders for daily self- } \\
\text { care such as meal times and drinking water } \\
\text { - It also provides reminder options for treatment-related activities such as } \\
\text { taking medicine, doctor's appointments and treatment appointments } \\
\text { - Reminders are sent in the form of push notifications on the date and time set } \\
\text { by the player }\end{array}$ \\
\hline $\begin{array}{l}\text { Diary Module } \\
\text { Related Theories: } \\
\text { PMT }\end{array}$ & $\begin{array}{l}\text { - To encourage the players to reflect on their situation } \\
\text { - Players can write new diary entries and view their past entries } \\
\text { - This module asks the players to rate their emotional and physical health } \\
\text { statuses } \\
\text { - It provides a checklist of common health-related problems experienced by } \\
\text { childhood cancer patients such as feeling hungry, having bowel movement } \\
\text { problems, and experiencing pain } \\
\text { - Should any of these problems be checked, the pet will give basic advice to } \\
\text { help the players and encourage them to seek help from their family and } \\
\text { health care providers } \\
\text { - The ability to self-reflect and express themselves [15], and share their } \\
\text { thoughts and experiences [33], were found to help young cancer patients to } \\
\text { cope positively }\end{array}$ \\
\hline Language Module & $\begin{array}{l}\text { - The game is available in three languages (English, Malay and Simplified } \\
\text { Chinese) to support the understanding of young children who are not fluent in } \\
\text { English }\end{array}$ \\
\hline $\begin{array}{l}\text { Pet Appearance } \\
\text { Module }\end{array}$ & - Allows the customization of the pet and pet home appearance \\
\hline Shop Module & $\begin{array}{l}\text { - Players can use the star coin virtual currency earned from mini-games to } \\
\text { purchase more appearance options for their pet }\end{array}$ \\
\hline $\begin{array}{l}\text { Tutorial and Help } \\
\text { Module }\end{array}$ & $\begin{array}{l}\text { - A tutorial is available upon the player's first entry to the game } \\
\text { - The pet demonstrates all the basic features to guide the player from one } \\
\text { game module to another } \\
\text { - A help button is available on all parts of the game to briefly explain the } \\
\text { current screen }\end{array}$ \\
\hline Incentive Module & $\begin{array}{l}\text { - Added to encourage the player to continue coming back to the game to play it } \\
\text { - Includes daily login bonuses, daily quests, daily gifts and game achievements }\end{array}$ \\
\hline
\end{tabular}


Figure 1 shows the screenshot of (a) the Home Screen where the player can access various game modules and take care of their pet, and also (b) the screenshot of the mini-game selection screen where players can choose a mini-game to play.

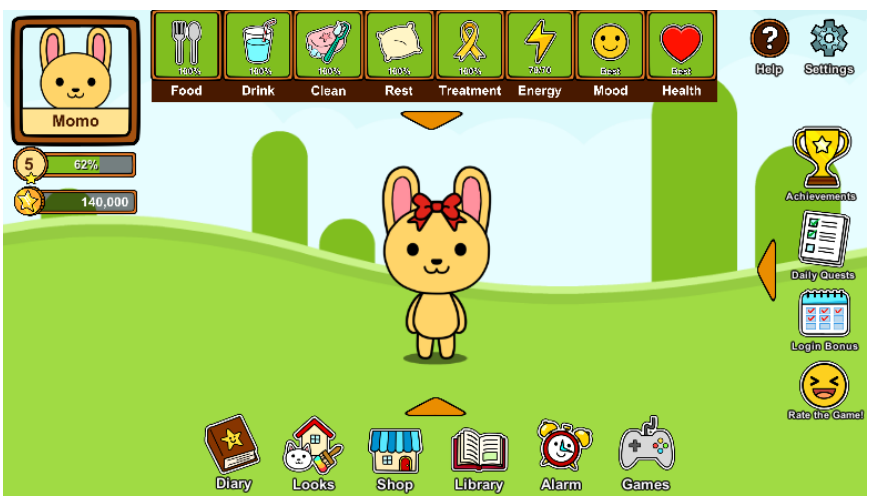

(a)

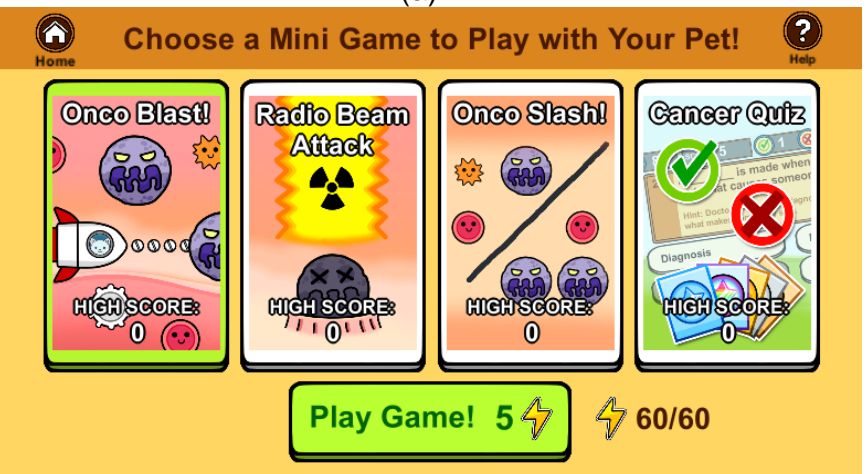

(b)

Figure 1. Screenshots from Pets vs Onco, (a) Home Screen where a player can access all the game modules, and (b) Mini Game Selection Screen

\section{Methods}

The pilot study for the Pets vs Onco serious game uses a single-arm pretest-posttest design to test the effectiveness of the intervention. Eight caregiver/child dyads were recruited from a boarding home for children with cancer who have agreed to collaborate on this research. The counsellor approached parents of potential participants and asked if they would like to participate in the study. Contacts of parents who would like to take part were obtained. The selection criteria for participants are:

\section{- Being 6-17 years old}

- Having at least one month of cancer treatment experience before the intervention begins

- Caregiver/child dyad can communicate, understand and read basic English/Malay/Simplified Chinese
- Having an Android mobile device with an internet connection which the game can be installed and played on

- Can play the game during the one month intervention period

Patients who are in end-of-life care are excluded from this study. Dropout criteria for participants include choosing not to continue with the intervention for any reason before completion of post-intervention surveys, if the participant has passed away, or if their circumstances now restrict them from continuing the study.

Due to the pandemic, the pilot evaluation was conducted digitally to maintain social distancing. During the first contact with the caregivers, they were asked to fill in the demographic survey to collect basic information about the participant, such as age, gender and how often they play mobile games. This survey was also used to determine if the potential participant met the selection criteria. Upon confirming the participant's eligibility, the researcher explained the entire study clearly to the caregivers and provided them with the information sheet. Informed parental consent was obtained for each participant.

Should caregivers and participants be available, the digital pre-intervention surveys were linked to the caregivers and participants. The caregivers were then guided through the installation of the game to the participant's mobile device. Additional assistance was provided for caregivers experiencing installation difficulties by SCCS. Upon successful installation, the in-game tutorial guided the caregivers and participants in playing the game. The participants were then left to play the game at their own pace for one month.

Caregivers of participants who were still with the study after one month were contacted for the post-intervention surveys. Once again, the digital surveys are linked. Upon completion, caregivers and participants were asked to provide their feedback via the end of intervention surveys. Caregivers who were willing were also asked additional follow-up questions to elaborate on their perspective of the game's impact on their children.

\subsection{Study Instruments and Outcomes}

The Protection Motivation Theory (PMT) used to inform the intervention's design was also used to create two evaluation surveys. There were two versions of the PMT surveys. One version to measure the participants' intentions, which was designed to be child friendly, and another to view the caregivers' perspective of participants' intentions. Caregivers of participants aged 12 and below were allowed to guide their children in filling the surveys.

Three pre-intervention and post-intervention (pretestposttest) surveys were used in this study.

(i) Protection Motivation Survey 1 - Using Cancer Treatment to Fight Cancer (PMT Survey 1) 
- A 5-point Likert Scale survey

- To measure the intention of participants to adhere to cancer treatment to fight cancer

(ii) Protection Motivation Survey 2 - Using Daily Self-care to Manage Cancer Treatment Side-Effects (PMT Survey 2)

- A 5-point Likert Scale survey

- To measure the intention to use daily self-care to manage treatment side-effects

(iii) Cancer Knowledge Survey

- A 20-question multiple-choice quiz

- It was created by adapting the information on cancer available online [34,35], which were written with children's reading levels in mind

- To measure the level of participants' knowledge of basic cancer and cancer treatment facts

After the post-intervention surveys, the participants and their caregivers' feedback was obtained via the End of Intervention Questionnaire. Questions for participants asked for their rating of the game and their likes and dislikes about it. Caregivers are also invited to discuss what they like and dislike and the game's usefulness for children with cancer. Caregivers who volunteered were asked additional follow-up questions to explore their views on how the game impacted their children. Responses of the follow-up were transcribed into text for qualitative data analysis.

\subsection{Plan of Analysis}

Descriptive statistics were used to summarize the results obtained from the pre-test and post-test surveys: PMT Survey 1 (cancer treatment), PMT Survey 2 (daily self-care) and the Cancer Knowledge Survey. Individual t-tests were used to determine if there are any significant differences between the responses of the caregiver and child participants for the PMT Surveys. Paired t-tests were used for hypothesis testing to compare the results between pre-and post-intervention for PMT Survey 1, PMT Survey 2 and Cancer Knowledge Survey.

For the End of Intervention Surveys and Follow up Questions for gathering feedback, the responses for yes or no questions, and the participants' ratings of how much they liked the game, were described with descriptive statistics. Qualitative feedback from both child and caregiver surveys and the follow-up done with caregivers were reviewed and coded for thematic analysis. Main themes were identified from the coding done, and the final codes were arranged as sub-themes within these main themes.

\section{Results}

\subsection{Demographics}

As of November 2021, 11 participants have been approached for the study from a single centre. Of these participants, ten had consented to participate; however, two had dropped out due to varied circumstances. Results from the 8 participants who have completed the intervention are presented in this paper.

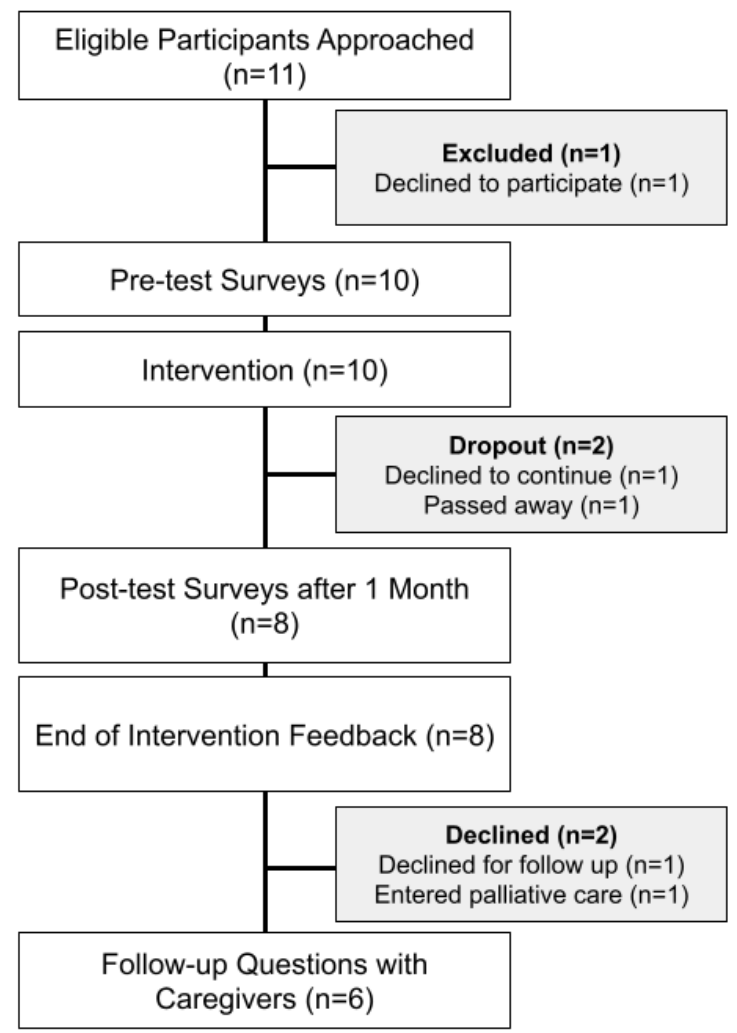

Figure 2. Flow Diagram for Design of Study

There are four male participants and four female participants. The participants' ages range from 8 to 16 years old $(\mathrm{M}=$ $12.38, \mathrm{SD}=2.87$ ). Caregivers reported that five participants played mobile games daily, two played several times a week but not daily, and one participant played around once a month. Table 2 shows the participant overview reported by the caregivers.

To monitor if the participants play the game during the intervention, Pets vs Onco can keep track of the activities performed by the participants during gameplay. These activities were compiled into an action log file which was sent to a secured server that only the researchers could access. From the action $\operatorname{logs}$ received, it was confirmed that all the participants played the game regularly during the intervention period. 
Table 2. Participant Overview

\begin{tabular}{llll}
\hline Participant & Age & Gender & $\begin{array}{l}\text { Frequency of playing } \\
\text { mobile games }\end{array}$ \\
\hline 1 & 14 & Male & Daily \\
2 & 11 & Female & Daily \\
3 & 13 & Male & Daily \\
4 & 14 & Female & Once a month \\
5 & 16 & Male & A few times a week \\
6 & 8 & Male & Daily \\
7 & 8 & Female & Daily \\
8 & 15 & Female & A few times a week \\
\hline
\end{tabular}

\subsection{Results for Protection Motivation Theory (PMT) Surveys}

\section{Difference between Caregiver and Child Survey Scores}

PMT Survey 1 results comparing the scores of children and caregivers' responses indicated no significant difference between the answers for 'the intention of using cancer treatment to fight cancer'. There was also no significant difference in PMT Survey 2 for 'the intention of using daily self-care to manage treatment side effects'.

\section{Hypothesis Testing}

Based on the individual t-tests conducted earlier, no significant differences were found between the intention values between the children and caregivers. Therefore, the one-tailed paired sample t-test was performed to compare the pre-and post-intervention results of both Protection Motivation Theory (PMT) Surveys used the average values of the responses from each caregiver and child dyad.

For the PMT Survey 1 to determine the participants' intention of using cancer treatment to fight cancer, there was a significant increase in the scores for the pre-intervention results $(\mathrm{M}=4.25, \mathrm{SD}=1.06)$ and the post-intervention results $(\mathrm{M}=4.81, \mathrm{SD}=0.40) ; \mathrm{p}=0.0327$. It indicates that the evidence is strong enough $(p<0.05)$ to suggest that the game intervention has affected the participants' motivation to keep up with their cancer treatment.

On the other hand, for the PMT Survey 2 to determine the participants' intention of using daily self-care to manage treatment side effects, there was no increase in the scores for the pre-intervention results $(\mathrm{M}=4.06, \mathrm{SD}=0.93)$ and the post-intervention results $(\mathrm{M}=4.06, \mathrm{SD}=0.68) ; \mathrm{p}=0.5$. It indicates insufficient evidence $(\mathrm{p}>0.05)$ to suggest that the game intervention has affected the participants' motivation to use daily self-care to manage their cancer treatment side effects.

\subsection{Results for Cancer Knowledge Survey}

For the Cancer Knowledge Survey, the results of each participant for the pre-and post-intervention surveys are depicted in Table 3 below.
Table 3. Summary of Cancer Knowledge Survey Pretest and Post-test Results

\begin{tabular}{|c|c|c|c|}
\hline Participant & $\begin{array}{l}\text { Pre-Test } \\
\text { Language }\end{array}$ & $\begin{array}{l}\text { Pre-Test } \\
\text { Total Score } \\
(100 \%)\end{array}$ & $\begin{array}{l}\text { Pre-Test } \\
\text { Level of } \\
\text { Understanding }\end{array}$ \\
\hline P1 & Malay & 35 & None \\
\hline P2 & Malay & 40 & Poor \\
\hline P3 & Malay & 40 & Poor \\
\hline P4 & Malay & 85 & Excellent \\
\hline P5 & Malay & 60 & Good \\
\hline P6 & Malay & 90 & Excellent \\
\hline P7 & Malay & 70 & Good \\
\hline \multirow[t]{3}{*}{ P8 } & Malay & 65 & Good \\
\hline & Mean (SD) & $\begin{array}{l}60.63 \\
(20.95) \\
\end{array}$ & \\
\hline & $\begin{array}{l}\text { Post-Test } \\
\text { Language }\end{array}$ & $\begin{array}{l}\text { Post-Test } \\
\text { Total Score } \\
(100 \%)\end{array}$ & $\begin{array}{l}\text { Post-Test } \\
\text { Level of } \\
\text { Understanding }\end{array}$ \\
\hline $\mathrm{P} 1$ & Malay & 40 & Poor \\
\hline P2 & Malay & 85 & Excellent \\
\hline P3 & Malay & 40 & Poor \\
\hline P4 & English & 55 & Satisfactory \\
\hline P5 & Malay & 65 & Good \\
\hline P6 & Malay & 80 & Excellent \\
\hline P7 & Malay & 70 & Good \\
\hline \multirow[t]{2}{*}{ P8 } & Malay & 80 & Excellent \\
\hline & Mean (SD) & $\begin{array}{l}64.38 \\
(17.81)\end{array}$ & \\
\hline
\end{tabular}

The observations indicate a minor improvement in overall scores and the level of understanding for participants during the post-test. Another observation was a stark decrease in Participant 4 (pre-test score $=85 \%$, post-test score $=55 \%$ ). The participant's understanding of the question may have been affected by the language chosen (pre-test taken in Bahasa Melayu, post-test taken in English), resulting in the decrease.

A one-tailed paired sample t-test was performed to compare the participants' pre-and post-intervention results of the Cancer Knowledge Surveys. There was no significant increase in the scores for the pre-intervention results $(\mathrm{M}=$ $60.63, \mathrm{SD}=20.95)$ and the post-intervention results $(\mathrm{M}=$ 64.38, $\mathrm{SD}=17.81) ; \mathrm{p}=0.3172$.

The surveys were done online with multi-language options. Participants were free to change the language of the survey form as they liked. Due to this, Participant 4 was allowed to take the survey in a different language during the post-test.

Therefore, the one-tailed paired sample t-test was repeated to compare the participants' results for the Cancer Knowledge Surveys, excluding Participant 4 . The improvement in scores was more evident as seen from the scores for the preintervention results $(\mathrm{M}=57.14, \mathrm{SD}=19.97)$ and the postintervention results $(\mathrm{M}=65.71, \mathrm{SD}=18.80) ; \mathrm{p}=0.1240$ is small.

The evidence is not strong enough $(p>0.05)$ to make a conclusive recommendation that the game intervention has impacted the participants' knowledge of cancer and treatment. 


\subsection{Results from End of Intervention Survey and Follow up Questions}

\section{Descriptive Statistics}

All caregivers $(n=8)$ who have answered the feedback survey agreed that Pets vs Onco was useful and helpful for children with cancer. In addition, all caregivers $(n=8)$ decided that the game was useful and practical for their child.

All caregivers who agreed to the follow-up $(n=6)$ have agreed that they have noticed positive differences in their children after playing the game. All caregivers $(n=6)$ agreed that the game encouraged their child to keep up with treatment and perform daily self-care. All caregivers $(n=6)$ also decided that the game has helped improve their children's knowledge about cancer and encourage conversation and discussion about this topic between them and their child.

\section{Game Ratings}

Participants were asked to rate the game on a scale of 1 to 5 : '1-strongly dislike', '2-dislike', '3-feeling neutral', '4-like', and '5-strongly like'.

Overall, most participants liked the game (Mean $=3.75$, $\mathrm{SD}=1.299)$. Out of the 8 participants, $3(37.5 \%)$ strongly liked the game (rating of 5), 2 (25\%) liked the game, $2(25 \%)$ felt neutral about the game, while only $1(12.5 \%)$ strongly disliked the game. When the participants were divided into two groups based on age, it can be seen that younger participants $(\mathrm{M}=4.75, \mathrm{SD}=0.433)$ enjoyed the game much more than the older participants $(\mathrm{M}=2.75, \mathrm{SD}=1.090)$. It may indicate that the game is better suited for a younger target audience and will require additional content to appeal to the older participants.

In this sample, gender does not strongly influence the game's rating, with a mean of 3.75 for both gender groups.

\section{Thematic Analysis}

The responses obtained from intervention surveys and follow-up questions were reviewed and analyzed for codes. Codes identified were categorized into sub-themes and used to identify main themes.

The main themes identified are:

$\begin{aligned} \text { (i) } & \text { Impacts on Cancer Treatment } \\ \text { (ii) } & \text { Impacts on Daily Self-care } \\ \text { (iii) } & \text { Other Benefits of the Game } \\ \text { (iv) } & \text { Likes about the Game } \\ \text { (v) } & \text { Dislikes about the Game } \\ \text { (vi) } & \text { Feedback/Suggestions for Improvement } \\ \text { (vii) } & \text { Others }\end{aligned}$

The main themes, sub-themes, frequency in which they were mentioned, and examples found in the thematic analysis are depicted in Table 4 below.

\section{Discussions}

This article describes the development and pilot evaluation of Pets vs Onco, a mobile game for educating young cancer patients about their illness and motivating them to keep up with their cancer treatment and daily self-care.

Quantitative survey results showed a significant increase in the participants' intention to use cancer treatment to fight cancer. However, there was no substantial change for the participants' preference to use daily self-care to manage treatment side effects and the Cancer Knowledge Survey scores.

The quantitative survey did not depict any improvement in the participants' intentions to use daily self-care; however, the caregivers' feedback showed that the game positively impacted the participants' use of daily self-care. The participants' quantitative pre-test and post-test surveys were self-reported motivation or belief in themselves to perform daily self-care, which has the tendency to be affected by their physical or emotional state at the time of the responses. On the other hand, the caregivers' feedback was based on their continuous observation of their children's abilities and attitudes towards daily self-care.

The game had an average rating of $\mathrm{M}=3.75$ out of 5 stars among the 8 participants. Grouping the participants by age highlighted that young participants $(M=4.75)$ enjoyed the game more than older participants $(M=2.75)$. There was no influence on the scores when participants were divided by gender $(M=3.75)$ for both gender groups.

The thematic analysis results show that the virtual pet game was able to help in terms of cancer treatment. Most participants and caregivers highlighted that the game had educated about cancer and cancer treatment and helped motivate participants to go through their treatment.

The game also impacted the participants' daily self-care; caregivers pointed out that children became more motivated to perform daily self-care and were more independent and punctual. The game also benefited the participants in various ways, such as helping them pass the time during treatment, opening conversation about cancer and treatment, cheering the participant up, and easing their stress.

Participants and caregivers liked the game for various reasons; the main reasons were the attractive graphics and benefit children with cancer. However, it was also pointed out that the game can get boring after a while and that there are words that may be difficult to understand for younger children. Improvements suggested include more mini-games attractive to young players and lessening the difficulty of the terms used to boost understanding.

\section{Limitations}

Our study has some limitations. For instance, as the same group of children used the same questions (Cancer Knowledge Survey) twice, a learning effect might have impacted the survey score. Also, there might be particular order effects in answering the survey that could play a role in 
determining the learning effects in our experiment. We believe that due to the time difference of one month between the pre and post-test, it was unlikely that participants could remember their earlier responses to the survey questions though we cannot completely ignore the learning effects. Further investigation is needed to generalise the findings of our pilot study.

\section{Conclusions and Future Work}

In conclusion, survey results suggests that the game Pets vs Onco can significantly increase the motivation of children with cancer to use cancer treatment to fight cancer. According to the end of feedback surveys and the follow-up questions, we can see that the game positively impacted the participants in terms of using cancer treatment and performing daily selfcare. The game was also liked by caregivers and enjoyed by the participants, especially the younger ones. Pets vs Onco will need to be extended in terms of gameplay content to address the feedback for improvement, engage the participants better and allow the game to be played for a longer period.

The pilot study outcomes support future work. The current work recruited of participants from Sarawak may not generalize the impact of the game for children with cancer. Further research is needed to evaluate the game on a larger scale. The recruitment for future studies may have a waitlist control group and should also be extended to multiple locations to boost diversity and the number of samples.

\section{Acknowledgements.}

The authors would like to thank the children and their families from the Sarawak Children's Cancer Society (SCCS) who participated in this study. We also thank the wonderful people from SCCS for their support in facilitating the recruitment process. Swinburne Sarawak HDR scholarship funded the research project. The study has approval from the Swinburne University Human Research Ethics Committee (SUHREC 20202689-3990). 
Table 4. Thematic Analysis - Coding Themes and Sub-theme Frequencies and Examples

\begin{tabular}{|c|c|c|c|c|}
\hline No. & Theme & Sub-theme & Frequency & Examples \\
\hline \multirow{2}{*}{1} & \multirow{2}{*}{$\begin{array}{l}\text { Impacts on } \\
\text { Cancer } \\
\text { Treatment }\end{array}$} & $\begin{array}{l}\text { The game teaches about } \\
\text { cancer and/or treatment }\end{array}$ & 17 & $\begin{array}{l}\text { "...the game taught my son about my son's cancer } \\
\text { treatment completely." } \\
\text { "...she knows chemotherapy treatment kills cancer } \\
\text { cells in her body." }\end{array}$ \\
\hline & & $\begin{array}{l}\text { More motivated about } \\
\text { treatment }\end{array}$ & 7 & $\begin{array}{l}\text { "...making him stronger to fight the disease and } \\
\text { recover completely." } \\
\text { "...he believes that the disease can be cured if he does } \\
\text { the treatment." }\end{array}$ \\
\hline \multirow{3}{*}{2} & \multirow{3}{*}{$\begin{array}{l}\text { Impacts on } \\
\text { Daily Self-care }\end{array}$} & $\begin{array}{l}\text { More motivation for daily } \\
\text { self-care }\end{array}$ & 7 & $\begin{array}{l}\text { "...after eating, he took his own medicine, he went to } \\
\text { take a shower." } \\
\text { "...he is now diligent in taking care of his teeth and } \\
\text { taking a shower too. [laugh]" }\end{array}$ \\
\hline & & $\begin{array}{l}\text { Becoming more punctual } \\
\text { (about daily self-care \& } \\
\text { medication, or in general) }\end{array}$ & 4 & $\begin{array}{l}\text { "...she can remember when she needs to eat, drink } \\
\text { milk and take medicine." } \\
\text { "He is more punctual in comparison. ...he often asks if } \\
\text { the time is right to take his medicine. [laugh]" }\end{array}$ \\
\hline & & $\begin{array}{l}\text { The game teaches about } \\
\text { daily self-care }\end{array}$ & 1 & $\begin{array}{l}\text { "She drinks milk every day. ... she knows now why she } \\
\text { needs to drink enough water every day." }\end{array}$ \\
\hline \multirow{5}{*}{3} & \multirow{5}{*}{$\begin{array}{l}\text { Other Benefits } \\
\text { of the Game }\end{array}$} & $\begin{array}{l}\text { The game helps to pass the } \\
\text { time (during treatment and in } \\
\text { general) }\end{array}$ & 5 & $\begin{array}{l}\text { "Sometimes I see her playing this pets game while she } \\
\text { is undergoing chemo treatment if there is nothing to } \\
\text { do." } \\
\text { "Playing this game, I did not feel bored during my } \\
\text { treatment." }\end{array}$ \\
\hline & & $\begin{array}{l}\text { The game opens the } \\
\text { conversation about illness }\end{array}$ & 5 & $\begin{array}{l}\text { "...he thinks that this (cancer and treatment) is } \\
\text { important to share and understand." }\end{array}$ \\
\hline & & The game cheers child up & 3 & $\begin{array}{l}\text { "He can't play outside. ... if he doesn't play games, he's } \\
\text { just bored; if he plays games, he's a little happy." } \\
\text { "... when she first started playing this pets game, it was } \\
\text { really fun for her. ...she is very cheerful to play this } \\
\text { game." }\end{array}$ \\
\hline & & $\begin{array}{l}\text { Playing the game eases } \\
\text { stress (from illness and other } \\
\text { stressors) }\end{array}$ & 2 & $\begin{array}{l}\text { "...he forgot about the illness while playing the game." } \\
\text { "Also, while the doctor [laugh] was lecturing her due to } \\
\text { not complying with the rules set by the doctor, I see her } \\
\text { hands keep playing this game. [laugh]" }\end{array}$ \\
\hline & & More motivation in life & 1 & $\begin{array}{l}\text { "(The game) taught my child the meaning of a better } \\
\text { life despite having cancer and work harder to heal and } \\
\text { become stronger." }\end{array}$ \\
\hline \multirow{5}{*}{4} & \multirow{5}{*}{$\begin{array}{l}\text { Likes about the } \\
\text { Game }\end{array}$} & $\begin{array}{l}\text { The game has attractive } \\
\text { graphics }\end{array}$ & 3 & $\begin{array}{l}\text { "I love the colours in this game. The colours in this } \\
\text { game are very attractive." }\end{array}$ \\
\hline & & $\begin{array}{l}\text { The game can be beneficial } \\
\text { for children with cancer }\end{array}$ & 3 & $\begin{array}{l}\text { "Opens one's mind and adds more knowledge to my } \\
\text { son's current life." }\end{array}$ \\
\hline & & $\begin{array}{l}\text { The child enjoys virtually } \\
\text { treating and fighting cancer }\end{array}$ & 1 & "I love this game to treat cancer and to fight cancer." \\
\hline & & $\begin{array}{l}\text { The child enjoys taking care } \\
\text { of the pet }\end{array}$ & 1 & "(I like) Giving the cat food (in this game)." \\
\hline & & $\begin{array}{l}\text { The game reminds the child } \\
\text { of a popular mobile game }\end{array}$ & 1 & "This game is like Talking Tom." \\
\hline \multirow[b]{2}{*}{5} & \multirow{2}{*}{$\begin{array}{l}\text { Dislikes about } \\
\text { the Game }\end{array}$} & $\begin{array}{l}\text { The game is boring or gets } \\
\text { boring later }\end{array}$ & 7 & $\begin{array}{l}\text { "Fun. But sometimes boring. } \\
\text { "Not interesting." }\end{array}$ \\
\hline & & $\begin{array}{l}\text { Game is difficult to } \\
\text { understand for younger } \\
\text { children }\end{array}$ & 2 & $\begin{array}{l}\text { "(The game has) too many words, made my head } \\
\text { dizzy." }\end{array}$ \\
\hline 6 & $\begin{array}{l}\text { Feedback/ } \\
\text { Suggestions for } \\
\text { Improvement }\end{array}$ & The game can be improved & 3 & $\begin{array}{l}\text { "Just include the latest games the kids are interested } \\
\text { in." } \\
\text { "Reduce the use of difficult to understand words." }\end{array}$ \\
\hline \multirow[t]{2}{*}{7} & \multirow[t]{2}{*}{ Others } & $\begin{array}{l}\text { The child is curious about } \\
\text { cancer and treatment-related } \\
\text { information }\end{array}$ & 2 & $\begin{array}{l}\text { "...he's the curious sort who likes to ask questions." } \\
\text { "...sometimes she asks me something I don't know } \\
\text { and don't understand. I say search it on Google... } \\
\text { [laugh]." }\end{array}$ \\
\hline & & $\begin{array}{l}\text { The child had problems } \\
\text { putting the game down }\end{array}$ & 1 & $\begin{array}{l}\text { "Sometimes when she is told to eat, she is still busy } \\
\text { playing this game, though." }\end{array}$ \\
\hline
\end{tabular}




\section{References}

[1] Pritchard-Jones K, Pieters R, Reaman GH, Hjorth L, Downie P, Calaminus G, et al. Sustaining innovation and improvement in the treatment of childhood cancer: Lessons from high-income countries. Lancet Oncol 2013;14:e95103. https://doi.org/10.1016/S1470-2045(13)70010-X.

[2] Friedrich P, Lam CG, Kaur G, Itriago E, Ribeiro RC, Arora RS. Determinants of treatment abandonment in childhood cancer: Results from a global survey. PLoS One 2016;11:e0163090. https://doi.org/10.1371/journal.pone.0163090.

[3] McCulloch R, Hemsley J, Kelly P. Symptom management during chemotherapy. Paediatr Child Heal (United Kingdom) 2018;28:189-95. https://doi.org/10.1016/j.paed.2018.02.003.

[4] Alcoser PW, Rodgers C. Treatment strategies in childhood cancer. J Pediatr Nurs 2003;18:103-12. https://doi.org/10.1053/jpdn.2003.10.

[5] Hedén L, Pöder U, Von Essen L, Ljungman G. Parents' perceptions of their child's symptom burden during and after cancer treatment. J Pain Symptom Manage 2013;46:366-75. https://doi.org/10.1016/j.jpainsymman.2012.09.012.

[6] SIOP Working Committee on Psychosocial Issues in Pediatric Oncology. Guidelines for refusal, non-compliance and abandonment of treatment in children and adolescents 2002.

https://www.childhoodcancerinternational.org/guidelinesfor-refusal-non-compliance-and-abandonment-oftreatment-in-children-and-adolescents/ (accessed July 23, 2019).

[7] American Cancer Society. Preventing Infections in People With Cancer 2015. https://www.cancer.org/treatment/treatments-and-sideeffects/physical-side-effects/infections/preventinginfections-in-people-with-cancer.html (accessed July 23, 2019).

[8] Sala A, Rossi E, Antillon F, Molina AL, De Maselli T, Bonilla $\mathrm{M}$, et al. Nutritional status at diagnosis is related to clinical outcomes in children and adolescents with cancer: A perspective from Central America. Eur $\mathrm{J}$ Cancer 2012;48:243-52.

https://doi.org/10.1016/j.ejca.2011.06.006.

[9] Wilkes PA, Allen DH. Nutrition Care: Managing Symptoms From Cancer. J Nurse Pract 2018;14:267-275.e3. https://doi.org/10.1016/j.nurpra.2018.01.011.

[10] Virizuela JA, Camblor-Álvarez M, Luengo-Pérez LM, Grande E, Álvarez-Hernández J, Sendrós-Madroño MJ, et al. Nutritional support and parenteral nutrition in cancer patients: an expert consensus report. Clin Transl Oncol 2018;20:619-29. https://doi.org/10.1007/s12094-0171757-4.

[11] Walter LM, Nixon GM, Davey MJ, Downie PA, Horne RSC. Sleep and fatigue in pediatric oncology: A review of the literature. Sleep Med Rev 2015;24:71-82. https://doi.org/10.1016/j.smrv.2015.01.001.

[12] David CL, Williamson K, Tilsley DWO. A small scale, qualitative focus group to investigate the psychosocial support needs of teenage young adult cancer patients undergoing radiotherapy in Wales. Eur J Oncol Nurs 2012;16:375-9. https://doi.org/10.1016/j.ejon.2011.08.002.

[13] Jones JK, Kamani SA, Bush PJ, Hennessy KA, Marfatia A, Shad AT. Development and evaluation of an educational interactive CD-ROM for teens with cancer. Pediatr Blood Cancer 2010;55:512-9. https://doi.org/10.1002/pbc.22608.

[14] Nijhof SL, Vinkers CH, van Geelen SM, Duijff SN, Achterberg EJM, van der Net J, et al. Healthy play, better coping: The importance of play for the development of children in health and disease. Neurosci Biobehav Rev 2018;95:421-9. https://doi.org/10.1016/j.neubiorev.2018.09.024.

[15] Phillips CR, Davis LL. Psychosocial Interventions for Adolescents and Young Adults with Cancer. Semin Oncol Nurs https://doi.org/10.1016/j.soncn.2015.05.004

[16] Stålberg A, Sandberg A, Söderbäck M, Larsson T. The child's perspective as a guiding principle: Young children as co-designers in the design of an interactive application meant to facilitate participation in healthcare situations. J Biomed Inform 2016;61:149-58. https://doi.org/10.1016/j.jbi.2016.03.024.

[17] Rogers RW. A Protection Motivation Theory of Fear Appeals and Attitude Change. J Psychol 1975;91:93-114. https://doi.org/10.1080/00223980.1975.9915803.

[18] Maddux JE, Rogers RW. Protection motivation and selfefficacy: A revised theory of fear appeals and attitude change. J Exp Soc Psychol 1983;19:469-79. https://doi.org/10.1016/0022-1031(83)90023-9.

[19] Bui L, Mullan B, Mccaffery K. Protection motivation theory and physical activity in the general Population: A systematic literature review. Psychol Heal Med 2013;18:522-42. https://doi.org/10.1080/13548506.2012.749354.

[20] Baghianimoghadam MH, Mohammadi S, Noorbala MT, Mazloomy SS. An intervention based on protection motivation theory in reducing skin cancer risk. J Pakistan Assoc Dermatologists 2011;21:141-8.

[21] Wu YP, Nagelhout E, Aspinwall LG, Boucher K, Parsons BG, Kohlmann W, et al. A novel educational intervention targeting melanoma risk and prevention knowledge among children with a familial risk for melanoma. Patient Educ Couns 2018;101:452-9. https://doi.org/http://dx.doi.org/10.1016/j.pec.2017.10.008.

[22] Bandura A, Walters RH. Social learning theory. Englewood $\begin{array}{lll}\text { Cliffs, } & \text { NJ: } & \text { Prentice-hall; } \\ \end{array}$ https://doi.org/10.1111/j.1460-2466.1978.tb01621.x.

[23] Seidel N, Fieber V, Breitbart EW, Bornhäuser M, Stölzel F. Cluster Randomized Trial: Sun Protection Intervention 'Clever in Sun and Shade for Preschools'-Effectiveness and Dissemination. Child 2021, Vol 8, Page 651 2021;8:651. https://doi.org/10.3390/CHILDREN8080651.

[24] Farrow C, Belcher E, Coulthard H, Thomas JM, Lumsden J, Hakobyan L, et al. Using repeated visual exposure, rewards and modelling in a mobile application to increase vegetable acceptance in children. Appetite 2019;141:104327. https://doi.org/10.1016/j.appet.2019.104327.

[25] Chai CWE, Lau BT, Al Mahmud A, Tee MKT. A survey of digital health interventions for children with cancer. Int $\mathbf{J}$ Serious Games 2020;7:71-88. https://doi.org/10.17083/ijsg.v7i2.340.

[26] Chai CWE, Lau BT, Al Mahmud A, Tee MKT. A Virtual Pet Serious Game in Motivating Children with Cancer in Treatment and Self-Care: A Conceptual Design. Malaysian J Paediatr Child Heal 2020;26:6-19. https://doi.org/10.51407/mjpch.v26i2.101.

[27] Oxford University Press. Definition of cyber pet 2018. https://en.oxforddictionaries.com/definition/us/cyberpet (accessed November 3, 2018).

[28] Laskowski A. New Apps Teach Kids about Their Health. Bost Univ 2016. http://www.bu.edu/today/2016/wizdy- 
pets-educates-kids-how-to-manage-asthma-symptoms/ (accessed October 21, 2018).

[29] Ahn SJG, Johnsen K, Robertson T, Moore J, Brown S, Marable A, et al. Using Virtual Pets to Promote Physical Activity in Children: An Application of the Youth Physical Activity Promotion Model. J Health Commun 2015;20:807-15. https://doi.org/10.1080/10810730.2015.1018597.

[30] Ahn SJG, Johnsen K, Moore J, Brown S, Biersmith M, Ball C. Using Virtual Pets to Increase Fruit and Vegetable Consumption in Children: A Technology-Assisted Social Cognitive Theory Approach. Cyberpsychology, Behav Soc Netw 2015;19:86-92. https://doi.org/10.1089/cyber.2015.0224.

[31] Chai CWE, Lau BT, Al Mahmud A, Tee MKT. A multimedia solution to motivate childhood cancer patients to keep up with cancer treatment. MMAsia '20 Proc. 2nd ACM Int. Conf. Multimed. Asia, Association for Computing Machinery (ACM); 2021, p. 1-5. https://doi.org/10.1145/3444685.3446262.

[32] Kato PM, Cole SW, Bradlyn AS, Pollock BH. A Video Game Improves Behavioral Outcomes in Adolescents and Young Adults With Cancer: A Randomized Trial. Pediatrics 2008;122:e305-17. https://doi.org/10.1542/peds.20073134.

[33] Odh I, Löfving M, Klaeson K. Existential challenges in young people living with a cancer diagnosis. Eur J Oncol Nurs 2016;24:54-60. https://doi.org/10.1016/j.ejon.2016.08.005.

[34] The Cancer Council NSW. Talking to Kids About Cancer: A guide for people with cancer, their families and friends. The Cancer Council NSW; 2012.

[35] Douglas D. What is Cancer? Nemours Found 2016. https://kidshealth.org/en/kids/cancer.html\#catcancer (accessed September 12, 2019). 